\title{
Biocontrol of rice sheath blight with microorganisms obtained in rice cultivated soils
}

\author{
Estiben Caviedes Zambrano (D), Amanda Silva Parra ${ }^{1}$ (D), Ángela María Mogollón Ortizi,* (D), \\ 1. Universidad de los Llanos - Facultad de Ciencias Agropecuarias y Recursos Naturales - Escuela de Ingeniería en Ciencias Agrícolas - \\ Villavicencio (Meta), Colombia. \\ Received: Aug. 10, 2020 | Accepted: Dec. 7, 2020 \\ Section Editor: Robson Di Piero \\ *Corresponding author: amogollon@unillanos.edu.co \\ How to cite: Caviedes, E. Z., Silva, A. P., Mogollón, A. M. O. (2021). Biocontrol of rice sheath blight with microorganisms obtained in rice \\ cultivated soils. Bragantia, 80, e0921. https://doi.org/10.1590/1678-4499.20200356
}

\begin{abstract}
Actinobacteria of the genus Streptomyces are part of the soil microbiota from rice-growing areas and along with other microorganisms, such as Trichoderma spp., combine to act as natural enemies against the destructive soil-borne pathogen Rhizoctonia solani, causal agent of rice sheath blight disease. In this study, seven actinobacteria of the genus Streptomyces and three fungi of the genera Trichoderma and Purpureocillium were isolated from soils cultivated with rice using the serial dilution method. Streptomyces spp. M2A2 was selected for its ability to significantly reduce the in vitro growth of $R$. solani by $52 \%$ after $96 \mathrm{~h}$ by antibiosis in dual culture, while in the control treatment the mycelial growth was $100 \%$. Furthermore, biocontrol efficacy of treated plants of the susceptible cultivar Fedearroz 68 with actinobacteria was confirmed and the onset of symptoms were delayed up to 14 days, compared to the control treatment. Rice plants treated with Streptomyces spp. M2A2 showed lesions of $R$. solani reaching $0.7 \%$ of the plant height, the effectiveness of this treatment was similar to the difenoconazole treatment, whereas in the control treatment, the lesions covered $34 \%$ of the plant height. When compared to the antagonist fungus Trichoderma spp. M2H1, Streptomyces spp. M2A2 presented a better performance of biological control. The results clearly demonstrated that Streptomyces spp. M2A2 isolate from soils of rice growing areas has biocontrol efficiency against $R$. solani and therefore can be a promising biocontrol agent.
\end{abstract}

Key words: actinobacteria, Streptomyces spp., fungal phytopathogen, Oryza sativa.

\section{INTRODUCTION}

Different fungi affect the quality and quantity of the production of the rice crop Oryza sativa (Cuevas and Higuera 2018). One of which is Rhizoctonia solani, a causal agent of rice sheath blight, one of the most destructive soil-borne pathogens in rice-growing regions (El-Shafey et al. 2019; Jia et al. 2013).

Out of the disease management strategies, pest management is considered the most common and efficient component (Mahmood et al. 2017), however, modern agricultural systems point to the search for alternatives that guarantee crop protection and sustainable production without negative effects (Kunova et al. 2016). Biocontrol agents constitute a sustainable control method of plant pathogens (Massart et al. 2015).

In nature, plants are associated with microbial communities (Berg et al. 2017; Massart et al. 2015) that are recruited by the plant from microbiota present around the roots (Vandenkoornhuyse et al. 2015), that guarantees soil health and plant protection product plant-microorganism interaction (Vandenkoornhuyse et al. 2015). In search of agriculturally important microorganisms, the soil is an important source of natural enemies. An example is the abundance and prevalence of Streptomyces species in soil suppressive to R. solani (Cordovez et al. 2015).

Previous studies showed that Streptomyces can be a relevant biocontrol agent of different soil borne pathogens, including R. solani (Singh et al. 2016; Tamreihao et al. 2016; Wu et al. 2019), Fusarium oxysporum f. sp. lycopersici (Abbasi et al. 2019) 
and Phytophthora capsici (Park et al. 2012). Additionally, Streptomyces species demonstrate biocontrol efficacy in different crops, including rice (Boukaew et al. 2013; Prabavathy et al. 2006; Wu et al. 2019; Yang et al. 2017), tomato (Goudjal et al. 2014) and cucumber (Ohike et al. 2018).

Several mechanisms can be involved in the biological control provided by Streptomyces, such as antibiosis. Volatile organic compounds can inhibit the mycelial growth of soil-borne pathogens (Boukaew et al. 2013; Cordovez et al. 2015), likewise, the production of antibiotics by Streptomyces spp. affects the development of pathogens like R. solani (Wu et al. 2019).

Antagonistic activity of Streptomyces species has also been associated with the release of the cell wall degrading enzymes 1,3- $\beta$-d-glucanase (Park et al. 2012) and chitinase and $\beta-1,3$ glucanase against $R$. solani. In addition, Streptomyces species can provide control via induced systemic resistance (ISR) against $R$. solani (Patel et al. 2018; Singh et al. 2016) and Fusarium oxysporum f. sp. lycopersici (Abbasi et al. 2019).

Considering the importance of soil microorganisms in plant fitness and plant protection, the main goal of the present study was to select microorganisms isolated from rice-growing areas with in vitro and in vivo biocontrol potential against R. solani.

\section{METHODOLOGY}

The experiments were carried out in two phases, firstly in vitro antagonism assay of microorganisms against $R$. solani and secondly in vivo biocontrol trials in susceptible rice plants.

As part of the in vitro research, seven actinobacteria of the genus Streptomyces, according to morphological characteristics (M1A1, M2A1, M2A2, M2A3, M3A1, M3A2, M3A3), and three fungi of the genera Trichoderma (M2H1) and Purpureocillium (M3H1and. M3H2) from soil rice-growing areas in Villavicencio-Meta, Colombia were isolated using the serial dilution method (Faheem et al. 2015). The pathogen $R$. solani was isolated from rice plants with symptoms of sheath blight disease, following the tissue disinfection methodology by Ramos-Molina et al. (2016).

The in vitro antifungal activity of strains against $R$. solani was performed using the dual culture technique in potato dextrose agar (PDA) (Tagele et al. 2018). Mycelium discs (5 mm in diameter) of each fungal isolation and R. solani were placed on the opposite side of each Petri dish $1 \mathrm{~cm}$ away from the edge. With the actinobacteria, a stretch mark was made on the opposite side of the pathogen $72 \mathrm{~h}$ earlier (Zhang et al. 2016). The absolute control consisted of $R$. solani and the chemical control comprised PDA supplemented with the fungicide difenoconazole $3 \mathrm{~mL} / \mathrm{L}$.

The calculation of in vitro biocontrol efficacy was carried out using the formula by Ezziyyani et al. (2004) (Eq. 1), which determines the percentage of pathogen growth inhibition (PGI):

$$
\mathrm{PGI}=(\mathrm{R} 1-\mathrm{R} 2) / \mathrm{R} 1 \times 100
$$

where $\mathrm{R} 1$ is the radius of the control pathogen and $\mathrm{R} 2$ is the radius of the pathogen in confrontation with each isolate.

The microorganism (M2A2) that provided the biocontrol of $R$. solani was identified at the genera level by molecular analysis. The ribosomal gene $16 \mathrm{~S}$ region was used for the actinobacteria. The Ribosomal Database Project (RDP) allowed for the determination of the genus.

In vivo biocontrol trials with the cultivar Fedearroz 68 susceptible to $R$. solani were carried out with microorganisms Streptomyces spp. M2A2 and Trichoderma spp. M2H1, which showed in vitro antagonistic potential. In addition, fungi Purpureocillium spp. M3H1 and Purpureocillium spp. M3H2 that presented PGI values greater than $49 \%$ were also evaluated.

The inoculum of antagonistic microorganisms and pathogen R. solani were multiplied in sterile rice grains (Uppala and Zhou 2018). The substrate used in the experiment was collected in a nonoperated area and treated with $10 \%$ formalin (Sharma et al. 1990; Irigoyen and Vela 2005). Plastic bags of polyethylene with a capacity of $5 \mathrm{~kg}$ were used.

Each microorganism, fungi and actinobacteria was adjusted to a concentration of $1 \times 10^{7}$ spores $^{\star} \mathrm{mL}^{-1}$. A $100 \mathrm{~mL}$ volume of the suspension was applied to the substrate three days before, at the time 'Fedearroz 68 ' was planted and later at 33 and 
62 days after sowing. The inoculum of $R$. solani was applied to the substrate as an $80 \mathrm{~mL}$ mycelium suspension per plant at the time of planting.

At the onset of the symptoms, the incidence of the disease at 95, 102 and 109 days and the rate of the disease at 109 days was determined following the formula presented in Eq. 2 (Sharma et al. 1990).

Disease index (\%): [Highest point where the lesion was observed $(\mathrm{cm}) /$ plant height $(\mathrm{cm})] \times 100$

The efficacy of the biocontrol was determined by applying the formula presented in Eq. 3 (Yu et al. 2017):

Efficacy of biocontrol $=[($ Control disease index - disease index in treated plants $) /$ control disease index $] \times 100 \%$

In vitro tests were performed in a completely randomized design and independently for fungal isolates and actinobacteria, with seven repetitions (Petri dishes) per treatment. At the in vivo tests, the same design was used with seven repetitions. Variance analysis (ANOVA) and the least significant difference (LSD) test $\mathrm{p} \leq 0.05$ were performed for comparison of means using the Sisvar software version 5.6. Biocontrol efficiency percentage values were transformed with Aseno.

\section{RESULTS AND DISCUSSION}

The results showed in vitro inhibiting the mycelium growth of R. solani with Streptomyces spp. M2A2 and Trichoderma spp. M2H1 demonstrating antifungal activity (Table 1 and Fig. 1).

Table 1. Percentage of growth inhibition (PGI) in vitro of $R$. solani by fungal and actinobacterial isolates $96 \mathrm{~h}$ after the start of the confrontation.

\begin{tabular}{|c|c|}
\hline \multicolumn{2}{|c|}{ Fungi } \\
\hline Treatment & PGI96h \\
\hline Purpureocillium spp. M3H1 & $49^{\mathrm{a}} \mathrm{C}$ \\
\hline Purpureocillium spp. $\mathrm{M} 3 \mathrm{H} 2$ & $52 c^{b}$ \\
\hline Trichoderma spp. M2H1 & $78 b$ \\
\hline Difenoconazole & $100 a$ \\
\hline \multicolumn{2}{|c|}{ Actinobacteria } \\
\hline Treatment & PGI $96 \mathrm{~h}$ \\
\hline Streptomyces spp. M2A1 & $21 e$ \\
\hline Streptomyces spp. M2A3 & $22 e$ \\
\hline Streptomyces spp. M3A2 & $26 \mathrm{de}$ \\
\hline Streptomyces spp. M3A1 & $33 \mathrm{~cd}$ \\
\hline Streptomyces spp. M3A3 & $32 \mathrm{~cd}$ \\
\hline Streptomyces spp. M1A1 & $39 c$ \\
\hline Streptomyces spp. M2A2 & $52 b$ \\
\hline Difenoconazole & $100 a$ \\
\hline
\end{tabular}

a PGI: Percentage of growth inhibition. PGI = [(radius of the control pathogen - radius of the pathogen in confrontation)/radius of the control pathogen $\times 100$. ${ }^{b}$ Different letters within the same column indicate significant differences according to the LSD test $(p \leq 0.05)$.

The actinobacteria Streptomyces spp. M2A2 significantly inhibited the mycelium growth of $R$. solani (data not shown) $24 \mathrm{~h}$ after the dual culture started and managed to maintain its antagonistic efficacy for up to $96 \mathrm{~h}$ with $52 \%$ inhibition of the growth of $R$. solani, which was significantly higher than the other actinobacteria isolates that ranged between 21 and $39 \%$ (Table 1). 
On the other hand, after just $72 \mathrm{~h}$ a significant antagonistic effect in vitro against $R$. solani of fungus Trichoderma spp. M2H1 was observed (data not shown). At $96 \mathrm{~h}$, the percentage of $R$. solani inhibition was $78 \%$ significantly higher than Purpureocillium spp. M3H1 and Purpureocillium spp. M3H2 with values of 49 and 52\%, respectively (Table 1). The mechanisms of action of antagonistic microorganisms varied: antibiosis activity by Streptomyces spp. M2A2 against R. solani was confirmed through mycelium growth inhibition (Fig. 1c) and Trichoderma spp. M2H1 competed for space and subsequently mycoparasites the R. solani hyphae (Fig. 1a, b).
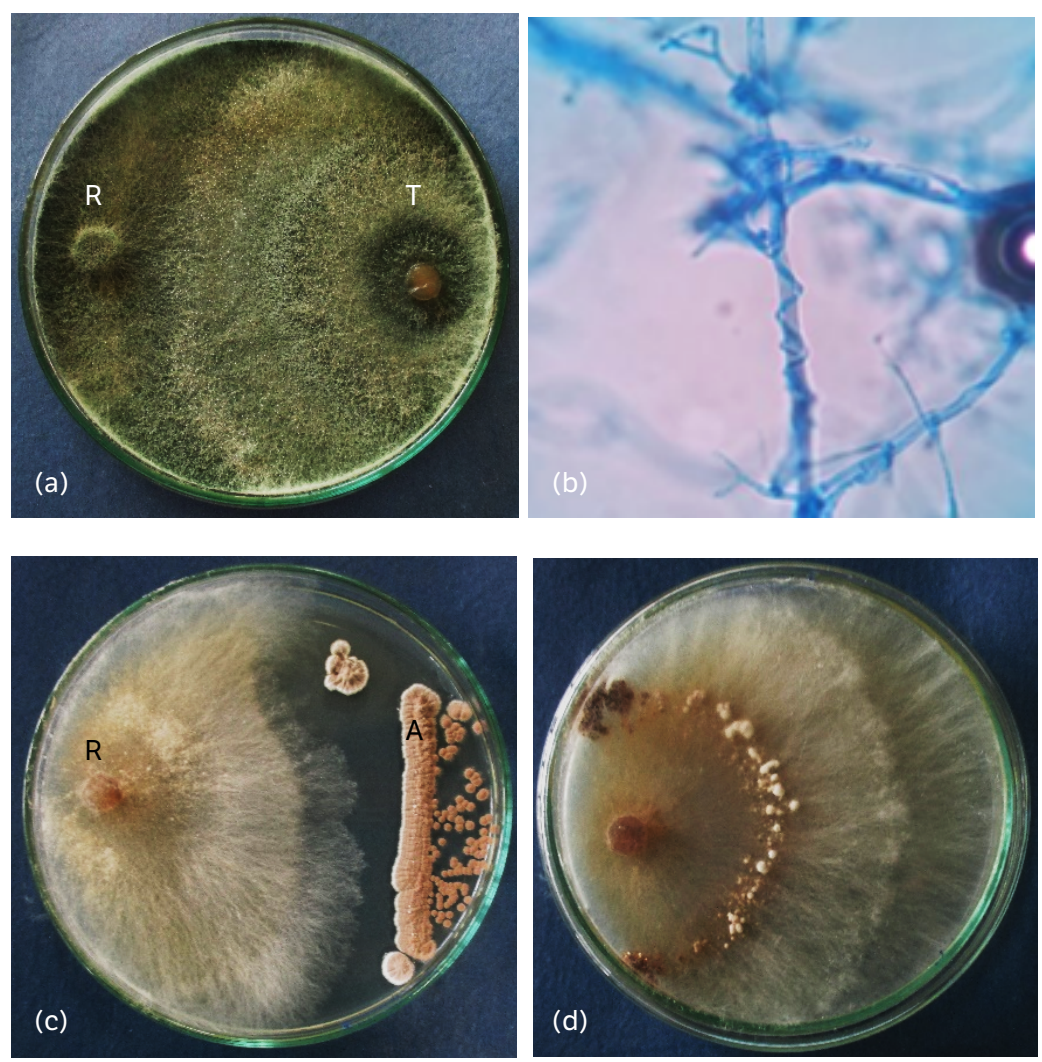

Figure 1. In vitro growth inhibition of $R$. solani by antagonistic microorganisms $96 \mathrm{~h}$ after the start of the confrontation. (a) Trichoderma spp. $\mathrm{M} 2 \mathrm{H} 1$ vs. $R$. solani. (b) Trichoderma spp. $\mathrm{M} 2 \mathrm{H} 1$ growing around the hyphae of $R$. solani. (c) Streptomyces spp. M2A2 creating a zone of inhibition against $R$. solani. (d) R. solani at 96 h. A: Actinobacteria. R: R. solani. T: Trichoderma spp.

In this work, the production of antifungal compounds by Streptomyces spp. M2A2 is likely to have caused antibiosis activity, which significantly inhibited growth in vitro of $R$. solani in dual culture (Fig. 1c). Previous reports confirm that members of the Streptomyces genus are recognized in producing different antifungal compounds. For instance, Cordovez et al. (2015) confirmed the inhibition of hyphal growth of $R$. solani by the volatile organic compounds (VOCs) methyl 2-methylpentanoate and 1,3,5-trichloro-2-methoxybenzene, produced by Streptomyces isolates obtained from a Rhizoctonia-suppressive soil. In another study, Boukaew et al. (2013) showed that the VOCs produced by Streptomyces philanthi RM-1-138 caused damage at cellular level by disrupting the cell walls, the formation of pores and distortions of the fungal hyphae, which drastically influenced the development of $R$. solani. In addition to VOCs, the antibiotic antifungalmycin (3-methyl-3,5-amino-4-vinyl-2-pyrone, $\mathrm{C} 6 \mathrm{H} 7 \mathrm{O} 2 \mathrm{~N}$ ) produced by Streptomyces spp. N2 affects the mycelial growth and sclerotia germination of the causal agent of rice sheath blight (Wu et al. 2019).

Furthermore, to the production of secondary metabolites, other Streptomyces species are known for the production of cell wall degrading enzymes against soil borne pathogens. Park et al. (2012) confirmed that antagonistic specie Streptomyces torulosus produced hydrolytic enzyme like $1,3-\beta$-d-glucanases that degrade the cell wall of Phytopthora capsici and $R$. solani and cause the inhibition of hyphal growth. Similarly, Tamreihao et al. (2016) reported antagonistic activity against $R$. solani by 
chitinase, $\beta$-1,3-glucanase and $\beta$-1,4-glucanase from Streptomyces corchorusii. In the same way, Yandigeri et al. (2015) confirmed the biocontrol efficacy against $R$. solani by chitinase enzyme production ability of Streptomyces vinaceusdrappus S5MW2.

In the in vitro results, the Trichoderma isolate $\mathrm{M} 2 \mathrm{H} 1$ showed typical mycoparasitic characteristic, growing over the R. solani hyphae (Fig. 1b), which is common for this biocontrol agent (Chen et al. 2016). In the plant trials, however, the stronger suppression was obtained with the Streptomyces isolate M2A2 (Table 2), showing that this microorganism may have a greater potential as to provide the biocontrol of rice sheath blight.

Table 2. Sheath blight index and efficacy of control of fungal and actinobacterial isolates in 'Fedearroz 68' plants at 109 days after sowing (das).

\begin{tabular}{ccc} 
Treatment & Disease index (\%) & Biocontrol efficacy (\%) \\
\hline Streptomyces spp. M2A2 & $0.7^{\mathrm{b}} \mathrm{c}^{\mathrm{a}}$ & $98^{\mathrm{c}} \mathrm{a}$ \\
\hline Difenoconazole & $3 \mathrm{c}$ & $90 \mathrm{ab}$ \\
\hline Trichoderma spp. M2H1 & $14 \mathrm{~b}$ & $63 \mathrm{bc}$ \\
\hline Purpureocillium spp. M3H2 & $22 \mathrm{ab}$ & $41 \mathrm{c}$ \\
\hline Purpureocillium spp. M3H1 & $22 \mathrm{ab}$ & $43 \mathrm{c}$ \\
\hline Control & $34 \mathrm{a}$ & - \\
\hline
\end{tabular}

a Values with different letters in the same column indicate significant difference according to the LSD test ( $p \leq 0.05)$. ${ }^{\mathrm{b}}$ Disease index (\%): [highest point where the lesion was observed $(\mathrm{cm}) /$ plant height $(\mathrm{cm})] \times 100 .{ }^{c}$ Biocontrol efficacy $=[($ control disease index - disease index in treated plants)/control disease index $]$ $\times 100 \%$. ${ }^{b-c}$ Values transformed with Aseno.

The preventive treatment of the soil with Streptomyces spp. M2A2 and, during the development of the rice plants, increased the incubation period of $R$. solani and reduced the progress of rice sheath blight disease. This effectiveness of biocontrol using actinobacteria was similar to the chemical treatment Difenoconazole. Streptomyces spp.M2A2 delayed the onset of symptoms until 109 days after sowing (DAS) in 'Fedearroz 68' plants, 14 days after the control treatment and isolates Purpureocillium spp. M3H2, Purpureocillium spp. M3H1 and, finally, the chemical difenoconazole where symptoms appeared at 95 DAS. Similar results were obtained showing an increase in the incubation period of the disease with Trichoderma spp. M2H1, with symptoms appearing at 102 DAS and 7 days after control treatment (data not shown).

These results are in concurrence with Ohike et al. (2018), whom selected Streptomyces lavenduligriseus KT from 53 actinobacteria isolated from soil samples, which demonstrated a growth inhibition effect against $R$. solani in vitro, subsequently in the treated plants (Cucumis sativus $\mathrm{L}$ ), the appearance of the symptoms of damping off was three days delayed.

The progression of $R$. solani lesions in the plants treated with Streptomyces spp. M2A2 reached $0.7 \%$ of the plant height, a significantly low percentage and similar to the treatment with difenoconazole. The efficacy percentages for these two treatments were 98 and 90\%, respectively. Furthermore, Trichoderma spp. M2H1 showed lesions that reached 14\% plant height and 63\% efficacy. In contrast, the control plants showed sheath blight lesions that reached $34 \%$ plant height (Table 2).

The results showed that the treatment of susceptible rice plants with Streptomyces spp. M2A2 increases the incubation period of the pathogen and reduces disease progression in treated plants. These results are in agreement with various reports which show that disease control activity can be influenced by different mechanisms that actinobacteria employs. For example, Wu et al. (2019) confirmed that the antifungalmycin N2 (3-methyl-3,5-amino-4-vinyl-2-pyrone, C6H7O2N) produced by Streptomyces ssp. guarantees healthy plant tissues, which is reflected by a reduced sheath blight severity as a consequence that inhibits sclerotia germination of $R$. solani. On the other hand, Boukaew et al. (2013) showed that volatile compounds of $S$. philanthi cause toxic effects against $R$. solani, which reduced the incidence and severity of rice leaf blight without having direct contact with rice plant tissues.

In addition, there are some reports available on Streptomyces spp. as a biocontrol agent via induced systemic resistance. Streptomyces-treated plants provide disease protection against $R$. solani associated with enhancing plant defense responses more efficiently, product the priming of plant defenses in response to treatment with Streptomyces spp. in the plant (Singh et al. 2016). Furthermore, the activation of phenylalanine ammonia lyase via and induction of ERF1 expression transcription factor involved in ET/JA in tomato by antagonistic Streptomyces isolates confirmed induced resistance against F. oxysporum f. sp. lycopersici (Abbasi et al. 2019). 
The confirmation of the genus of isolate M2A2 with the RDP classifier was able to determine that the sequence corresponded to the genus Streptomyces with 100\% confidence (GenBanK accession number MN428020).

\section{CONCLUSION}

In conclusion, the results showed that the soil is an important source that is beneficial to the microorganism. Streptomyces M2A2 disease was selected and demonstrated in vitro and in vivo biocontrol efficacy against $R$. solani causal agent of rice sheath blight. In addition to inhibiting the growth of $R$. solani, Streptomyces spp. M2A2 delayed the onset of symptoms and affected the progress of the pathogen in susceptible plants of the cultivar Fedearroz 68 without differences with the difenoconazole treatment and producing better results than Trichoderma spp. $\mathrm{M} 2 \mathrm{H} 1$ isolate. The results highlight the possibilities for using Streptomyces spp. in R. solani management.

\section{AUTHORS' CONTRIBUTION}

Conceptualization: Zambrano E. C., Parra A. S. and Ortiz A. M. M.; Methodology: Zambrano E. C., Parra A. S. and Ortiz A. M. M.; Investigation: Zambrano E. C. and Ortiz A. M. M.; Writing - Original Draft: Zambrano E. C. and Ortiz A. M. M.; Writing - Review and Editing: Ortiz A. M. M.; Funding Acquisition: Zambrano E. C., Parra A. S. and Ortiz A. M. M.; Resources: Parra A. S. and Ortiz A. M. M.; Supervision: Ortiz A. M. M.

\section{DATA AVAILABILITY STATEMENT}

All dataset were generated or analyzed in the current study.

\section{FUNDING}

Universidad de los Llanos

Proyecto VIAC-7426102016

\section{ACKNOWLEDGMENTS}

The authors are grateful to the Universidad de los Llanos, Meta, Colombia

\section{REFERENCES}

Abbasi, S., Safaie, N., Sadeghi, A. and Shamsbakhsh, M. (2019). Streptomyces Strains Induce Resistance to Fusarium oxysporum f. sp. lycopersici Race 3 in Tomato Through Different Molecular Mechanisms. Frontiers Microbiology, 10, 1505. https://doi.org/10.3389/ fmicb.2019.01505

Berg, G., Köberl, M., Rybakova, D., Müller, H., Grosch, R. and Smalla, K. (2017). Plant microbial diversity is suggested as the key to future biocontrol and health trends. FEMS Microbiology Ecology, 93, fix050. https://doi.org/10.1093/femsec/fix050 
Boukaew, S., Plubrukam, A. and Prasertsan, P. (2013). Effect of volatile substances from Streptomyces philanthi RM-1-138 on growth of Rhizoctonia solani on rice leaf. BioControl, 58, 471-482. https://doi.org/10.1007/s10526-013-9510-6

Chen, J.-L., Sun, S.-Z., Miao, C.-P., Wu, K., Chen, Y.-W., Xu, L.-H., Guan, H.-L. and Zhao, L.-X. (2016). Endophytic Trichoderma gamsii YIM PH30019: a promising biocontrol agent with hyperosmolar, mycoparasitism, and antagonistic activities of induced volatile organic compounds on root-rot pathogenic fungi of Panax notoginseng. Journal of Ginseng Research, 40, 315-324. https://doi.org/10.1016/j. jgr.2015.09.006

Cordovez, V., Carrion, V. J., Etalo, D. W., Mumm, R., Zhu, H., van Wezel, G. P. and Raaijmakers, J. M. (2015). Diversity and functions of volatile organic compounds produced by Streptomyces from a disease-suppressive soil. Frontiers Microbiology, 6, 1081. https://doi. org/10.3389/fmicb.2015.01081

Cuevas, A. and Higuera, O. and (2018). Guía para el monitoreo y manejo de enfermedades. Federación Nacional de Arroceros, Fedearroz. Adopción Masiva de Tecnología. Bogotá. [Accessed Jan. 20, 2019]. Available at: http://www.fedearroz.com.co/docs/cartilla_ enfermedades.pdf

El-Shafey, R. A. S., Elamawi, R. M., Saleh, M. M., Tahoon, A. M. and Emeran, A. A. (2019). Morphological, pathological and molecular characterisation of rice sheath blight disease causal organism Rhizoctonia solani AG-1 IA in Egypt. Archives of Phytopathology and Plant Protection, 52, 507-529. https://doi.org/10.1080/03235408.2019.1650544

Ezziyyani, M., Sánchez, C. P., Requena, M. E., Rubio, L. and Castillo, M. E. C. (2004). Biocontrol por Streptomyces rochei-Ziyani-, de la podredumbre del pimiento (Capsicum annuum L.) causada por Phytophthora capsici. Anales de Biología, 26, 61-68.

Faheem, M., Raza, W., Zhong, W., Nan, Z., Shen, Q. and Xu, Y. (2015). Evaluation of the biocontrol potential of Streptomyces goshikiensis YCXU against Fusarium oxysporum f. sp. niveum. Biological Control, 81, 101-110. https://doi.org/10.1016/j.biocontrol.2014.11.012

Goudjal, Y., Toumatia, O., Yekkour, A., Sabaou, N., Mathieu, F. and Zitouni, A. (2014). Biocontrol of Rhizoctonia solani damping-off and promotion of tomato plant growth by endophytic actinomycetes isolated from native plants of Algerian Sahara? Microbiological Research, 169, 59-65. https://doi.org/10.1016/j.micres.2013.06.014

Irigoyen, J. N. and Vela, M. A. C. (2005). Guía técnica de semilleros y viveros frutales. Santa Tecla: MAG, IICA, FRUTAL ES. [Accessed Mar. 15, 2019]. Available at: http://repiica.iica.int/docs/B0507e/B0507e.pdf

Jia, Y., Liu, G., Park, D.-S. and Yang, Y. (2013). Inoculation and scoring methods for rice sheath blight disease. In Y. Yang (Ed.), Rice Protocols. Methods in Molecular Biology (Methods and Protocols) (p. 257-268). Humana Press: Totowa. https://doi.org/10.1007/978-1-62703-194-3_19

Kunova, A., Bonaldi, M., Saracchi, M., Pizzatti, C., Chen, X. and Cortesi, P. (2016). Selection of Streptomyces against soil borne fungal pathogens by a standardized dual culture assay and evaluation of their effects on seed germination and plant growth. BMC Microbiol, 16, 272. https://doi.org/10.1186/s12866-016-0886-1

Mahmood, S., Lakra, N., Marwal, A., Sudheep, N. M., Anwar, K. (2017). Crop genetic engineering: an approach to improve fungal resistance in plant system. In D. P. Singh, H. B. Singh, and R. Prabha (Eds.), Plant-Microbe Interactions in Agro-Ecological Perspectives. (p. 581591). Singapore: Springer. https://doi.org/10.1007/978-981-10-6593-4_23

Massart, S., Martinez-Medina, M. and Jijakli, M. H. (2015). Biological control in the microbiome era: Challenges and opportunities. Biological Control, 89, 98-108. https://doi.org/10.1016/j.biocontrol.2015.06.003

Ohike, T., Maeda, M., Matsukawa, T., Okanami, M., Kajiyama, S. and Ano, T. (2018). In vitro and in vivo Assay for Assessment of the Biological Control Potential of Streptomyces sp. KT. Journal of Plant Studies 7, 10-16. https://doi.org/10.5539/.jps.v7n1p10

Park, J. K., Kim, J.-D., Park, Y. I. and Kim, S.-K. (2012). Purification and characterization of a 1,3--d-glucanase from Streptomyces torulosus PCPOK-0324. Carbohydrate Polymers, 87, 1641-1648. https://doi.org/10.1016/j.carbpol.2011.09.058 
Patel, J. K., Madaan, S. and Archana, G. (2018). Antibiotic producing endophytic Streptomyces spp. colonize above-ground plant parts and promote shoot growth in multiple healthy and pathogen-challenged cereal crops. Microbiological Research, 215, 36-45. https:// doi.org/10.1016/j.micres.2018.06.003

Prabavathy, V. R., Mathivanan, N. and Murugesan, K. (2006). Control of blast and sheath blight diseases of rice using antifungal metabolites produced by Streptomyces sp. PM5. Biological Control, 39, 313-319. https://doi.org/10.1016/j.biocontrol.2006.07.011

Ramos-Molina, L. M., Chavarro-Mesa, E., Pereira, D. A. S., Silva-Herrera, M. and Ceresini, P. C. (2016). Rhizoctonia solani AG-1IA infects both rice and signalgrass in the Colombian Llanos. Pesquisa Agropecuária Tropical, 46, 65-71. https://doi.org/10.1590/1983-40632016v4638696

Sharma, N. R., Teng, P. S. and Olivarce, F. M. (1990). Comparison of assessment methods for rice sheath blight disease. Philippines: Philippine Phytopathology.

Singh, S. P., Gupta, R., Gaur, R. and Srivastava, A. K. (2016). Streptomyces spp. alleviate Rhizoctonia solani-mediated oxidative stress in Solanum lycopersicon. Annals of Applied Biology, 168, 232-242. https://doi.org/10.1111/aab.12259

Tagele, S. B., Kim, S. W., Lee, H. G., Kim, H. S. and Lee, Y. S. (2018). Effectiveness of multi-trait Burkholderia contaminans KNU17BI1 in growth promotion and management of banded leaf and sheath blight in maize seedling. Microbiological Research, 214, 8-18. https:// doi.org/10.1016/j.micres.2018.05.004

Tamreihao, K., Ningthoujam, D. S., Nimaichand, S., Singh, E. S., Reena, P., Singh, S. H. and Nongthomba, U. (2016). Biocontrol and plant growth promoting activities of a Streptomyces corchorusii strain UCR3-16 and preparation of powder formulation for application as biofertilizer agents for rice plant. Microbiological Research, 192, 260-270. https://doi.org/10.1016/j.micres.2016.08.005

Uppala, S. and Zhou, X. G. (2018). Field efficacy of fungicides for management of sheath blight and narrow brown leaf spot of rice. Crop Protection, 104, 72-77. https://doi.org/10.1016/j.cropro.2017.10.017

Vandenkoornhuyse, P., Quaiser, A., Duhamel, M., Le Van, A. and Dufresne, A. (2015). The importance of the microbiome of the plant holobiont. New Phytologist, 206, 1196-1206. https://doi.org/10.1111/nph.13312

Wu, Z.-M., Yang, Y. and Li, K.-T. (2019). Antagonistic activity of a novel antifungalmycin N2 from Streptomyces sp. N2 and its biocontrol efficacy against Rhizoctonia solani. FEMS Microbiology Letters, 366, fnz018. https://doi.org/10.1093/femsle/fnz018

Yandigeri, M. S., Malviya, N., Solanki, M. K., Shrivastava, P. and Sivakumar, G. (2015). Chitinolytic Streptomyces vinaceusdrappus S5MW2 isolated from Chilika lake, India enhances plant growth and biocontrol efficacy through chitin supplementation against Rhizoctonia solani. World Journal of Microbiology and Biotechnology, 31, 1217-1225. https://doi.org/10.1007/s11274-015-1870-x

Yang, J.-H., Zhang, W.-W., Zhuang, Y.-Q. and Xiao, T. (2017). Biocontrol activities of bacteria from cowdung against the rice sheath blight pathogen. Journal of Plant Diseases and Protection, 124, 131-141. https://doi.org/10.1007/s41348-017-0080-1

Yu, Y.-Y., Jiang, C.-H., Wang, C., Chen, L.-J., Li, H.-Y., Xu, Q., Guo, J.-H. (2017). An improved strategy for stable biocontrol agents selecting to control rice sheath blight caused by Rhizoctonia solani. Microbiological Research 203, 1-9. https://doi.org/10.1016/j.micres.2017.05.006

Zhang, F., Ge, H., Zhang, F., Guo, N., Wang, Y., Chen, L., Ji, X. and Li, C. (2016). Biocontrol potential of Trichoderma harzianum isolate T-aloe against Sclerotinia sclerotiorum in soybean. Plant Physiology and Biochemistry, 100, 64-74. https://doi.org/10.1016/j.plaphy.2015.12.017 